\title{
INDEX TO VOLUME $\mathrm{x}$
}

A

Aвbotr (Nabia), The Rise of the North Arabic Script and its Kur'āinic Development, 794-6.

Abhidhānaratnamälà (Halāyudha), $1049 \mathrm{f}$.

Abrafam (R. C.), An Introduction to Spoken Hausa, 1057-1061 ; A Modern Grammar of Spoken Hausa, 10571061.

Abū MaWāhIB aL-Shädhilī, Illumination in Islamic Mysticism, 523.

Addendum, An (L. D. Barnett), 284 f.

Adnan (Abdulhakk), La science chez les Turcs Ottomans, $486 \mathrm{f}$.

AFrifi (A. E.), The Mystical Philosophy of Muhyid Din-Ibnul 'Arabi, $512 \mathrm{f}$.

Africa, Aspeets of Islam in Nineteenthcentury South (S. A. Rochlin), 213-21 ; Bird-nomenclature in an area of East, 998-1006.

African Survey, $A n$ (Lord Hailey), 551-3.

Afrikansche Negertalen, De Nominale Klassifikatie in de (J. Wils), $269 \mathrm{f}$.

After the Reforms: Communal versus Democratic Psychology (R. S. Vaidyanatha Ayyar), 814.

A Himad B. AL-Zubatr (Abū Ja'far), Silat al-sita, 522.

Aksum (U. Monneret de Villard), 254.

Alalakh and Chronology (Sidney Smith), $791 \mathrm{f}$.

Ālayavijĩāna, 238.

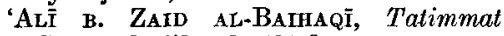
Siwän al.Hikmah, $520 \mathrm{f}$.

allan (Jorin), rev., 791, 814.

AlsdoRF (L.), Middle Indian Miscellanies, 19-23.

Alternance $2-\sim u$ - in Ancient Japanese, The (S. Yoshitake), 666-678.

Amharic, $807 \mathrm{f}$.

AL-ĀMIR BI-ẬKĀMI 'LLĀH, al-Hidàyatu 'l-Amiriya, 255-7.

ANDERSON (GEORGE), rev., $235 \mathrm{f}$.

Andreas (F. C.), Iranische Dialektaufzeichnungen, $1016 \mathrm{f}$.

ANDREws .(C. F.) and MoOkERJEe (GIRIS1), The Rise and Growth of the Congress, $815 \mathrm{f}$.

Another Ancient Tribe of the Panjab (L. D. Barnett), 277-284.

Anti-Christian Propaganda in the Mamlūk Empire, Notes on (M. Perlmann), 843-861.

AqUIIINA (ĠużE) Taht Tliet Saltniet, $263 \mathrm{f}$.

Arabia, Sa'ūdī, 1016 f.; Four Strange Tongues from South (B. Thomas), 251 f. : $A$ Winter in (F. Stark), 799 f.
Arabic, Everyday (H. M. Nahmad and C. Rabin), 801 .

Arabic and Persian Palaeography, Speci. mens of (A. J. Arberry), 802.

Arabic Manuscripts in the Library of the India Office, Catalogue of the (R. Levy), 796.

Arabic script, North, 794-6.

Arabic Thought and its Place in History (De L. O'Leary), 513.

Arabica and Islamica (U. Wayriffe), $1009,1012 \mathrm{f}$.

$L$ 'A rabo Parlato a S $\iota n^{\prime} \hat{a}^{\prime}$ (E. Rossi), $801 \mathrm{f}$. Arabs, History of the (P. K. Hitti), $530 \mathrm{f}$.

ARBerry (A. J.), A Rejoinder, 1065 f. ; Specimens of Arabic and Persian Palaeography, 802.

Archaeologische Mitteilungen aus Iran (edit. E. Herzfeld), 501-7.

'Arḍ-nāmah of Davāni, 141-178.

Armenian eras, 648-653; language, 510.

Armenians, adopted Iranian festivals and christianized pagan feasts, 632-653.

Artists of Iran, 199-211.

Ashton (E. O.), rev., 547-9.

Aspects of Islam in Nineteenth-Century South Africa (S. A. Rochlin), 213-221.

Atatürk and the True Nature of Modern Turkey (G. Tongas), 537.

Australian Aborigines, The (A. P. Elkin), 489-491.

Average Man in Early Islam, The (A. S. Tritton), 133-140.

Avesta Codex $K 5$, The, 500, $1019 \mathrm{f}$.

$\overline{\mathrm{A}} \mathrm{z}, 380 \mathrm{f} ., 391-5,609-611,624-8$.

\section{B}

Babylonian Chronology, $791 \mathrm{f}$.

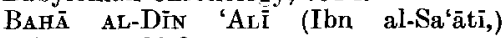
Dīwān, $521 \mathrm{f}$.

BAILEY (H. W.), Hvatanica IV, 886-924; Rāma, 365-376, 5. 59-598; Ttāgutta, 599-605; rev., 1019-1023, 1030.

BAKER (J. N. C.), Medieval Trade Routes, $531 \mathrm{f}$.

Bantu in the City, The (R. E. Phillips), 549-550.

Bantu-sprachen, Die mit B.-île gebildeten Perfektstämme in den (P. Berger), $270 \mathrm{f}$.

Barbary, Islam in, 515-17.

Barnett (L. D.), An Addendum, 284 f. ; Another Ancient Tribe of the Panjab, 277-284; Obituary: Commandant Joseph Gaspard Hackin, 1067 f.; Sinhalica, 284 f. ; rev., 236 f., 1051-4.

Barnett (R. D.) rev,, $1007 \mathrm{f}$. 
Barns (M.), The Indian Press, 819-821.

BeL (ALrRed), La Religion Musulmane en Berbérie, 515-17.

Bell (RichaRd), T'he Qur'än (transl.), 511 ; rev., 515-17.

Benveniste (E.), Codices Sogdiani, 1019-1021.

Berger (PAUL), Die mit B.-île gebildeten Perfektstämme in den Bantu-sprachen, $270 \mathrm{f}$.

Bibliography of Muslim Numismatics (L. A. Mayer), $1014 \mathrm{f}$.

Bibliography of Nutrition in India (N. Gangulee), 815.

Bird-nomenclature in an East African Area (R. E. Moreau), 998-1006.

BIRNBAUM (S.), rev., 258, 792-4, $1008 \mathrm{f}$.

Blagden (C. O.), edit., A Chinese Vocabulary of Cham Words and Phrases, 53-91 ; rev., $243 \mathrm{f}$.

Bodhisattvas, in religion of Khotan, $910 \mathrm{f}$.

Bonelli (Luigr), Lessico Turco-Italiano, 538.

Book of the Discipline, The, $1028 \mathrm{f}$.

Boveri (Margret), Minaret and Pipeline, $485 \mathrm{f}$.

Britton (Nancy Pence), A Study of some Early Islamic Textiles in the Museum of Fine Arts, Boston, $\mathbf{5 2 6 .}$

Brockelmanin (CARL), list of works of. 802.

Bryan (M. A.), rev., $1056 \mathrm{f}$.

Buddhas, in religion of Khotan, 886-910.

Buddhist Art in Siam, A Concise History of (R. le May), $242 \mathrm{f}$.

Buildings of Quaytbāy as described in his Endowment Deed, The, $529 \mathrm{f}$.

AL-BUKHĀRí, Sahīh, transl. by Muhammad Asad, $249 \mathrm{f}$.

Bulletin of the Faculty of Arts of the University of Egypt, $526 \mathrm{f}$.

Burmese Buddhist Law (O. H. Mootham), $822 \mathrm{f}$.

Burmese Music (Khin Zaw), 717-754; Proverbs (Kin Maung Lat), 31-51.

Burnow (T.), Dravidian Studies II, $289-297$; rev., 487 f., $1049 \mathrm{f}$.

\section{C}

Calendars used in countries of Islam, 107-132.

Califfo Mu'āwiya I, Il, 250.

Calligraphers and Artists (C. C. Edwards), 199-211.

Cat in Ancient Egypt, The (N. and B. Langton), $806 \mathrm{f}$.

Catalogue of the Arabic Manuscripts in the Library of the India Office, II, iv (R. Levy), 796.

Certains emplois d' $a(n)^{\circ}$ priv, en sanskrit, Sur (L. Renou), 1-18.
Cham words and phrases, A Chinese vocabulary of, 53-91.

Chinese MSS. in the Stein Collection, Dated, V (L. Giles), 317-344; Vocabulary of Cham Words and Phrases, A (edit. by E. D. Edwards and C. 0 . Blagden), 53-91.

Chingiz-Khān, Influence of his Yàsa upon organization of the Mamlūk State, 862-876.

Chintamani (Sir C. Yajneswara), Indian Politics since the Mutiny, $815 \mathrm{f}$.

Churchward (C. Maxwell), transl. of Tales of a Lonely Island, 824-6.

Cin, etymology of, 957-964.

Civil and Military Review in Fārs in 881/1476, A (V. Minorsky); 141-178.

Codices Sogdiani (E. Benveniste), 10191021.

ConEN (Marcel), Nouvelles Études d'Éthiopien Méridional, $807 \mathrm{f}$.

Combe (ÉTLNNe), Qafar-Khafara, 790.

Concepts of Riti and Guna in Sanskrit Poetics (P. C. Lahiri), 1031, $1048 \mathrm{f}$.

Concise History of Buddhist Art in Siam, A (R. le May), $242 \mathrm{f}$.

Congress, Indian National, $815 \mathrm{f}$.

Conker (OrHan) and WrTmeur (Émite), Redressement Économique et Industrialisation de la Nouvelle Turquie, 1016-18.

Contributions à l'Étude du Harari (W. Leslau), 252.

Coptic Dictionary, $A$ (W. E. Crum), 498500.

Coptica, Varia (W. E. Crum), $497 \mathrm{f}$.

Cremona (A.), Taghlim fuq il-Kitba Maltija, $268 \mathrm{f}$.

Critical Examination of the Philosophy of Religion, The (Śantinātha), $1031 \mathrm{f}$.

Crouchlex (A. E.), The Economic Development of Modern Egypt, 535-7.

Crowfoot (J. W. and G. M.), Early Ivories from Samaria, 792-4.

Croyances el coutumes persanes (H. Massé), $542-5$.

CRUM (W. E.), A Coptic Dictionary, 498-500; Varia Coptica, $497 \mathrm{f}$.

Cultural Heritage of India, The, 1031, 1041-3.

Cuneiform Texts of Ras Shamra, Ugarit, The (C. F. A. Schaeffer), $252 \mathrm{f}$.

\section{D}

Damascus just after the Ottoman Conquest, 179-184.

Dan̂, etymology of, 954-7.

DASqUPTA (Surendranath), A History of Indian Philosophy, 1031, 10391041.

Dated Chinese Manuscripts in the Stein Collection V (L. Giles), 317-344. 
Davānĩ (Jalāl al-Dīn Muḥ.), his 'Arḍnāmah, 141-178.

Davins (C. A. F. Rirxs), Wayfarer's Words, 1031, $1044 \mathrm{f}$.

Davies (C. ColLIN), Warren Hastings and Oudh, $480 \mathrm{f}$.

Debates Commentary, The, $1028 \mathrm{f}$.

Debevorse (NeIlson C.), $A$ Political History of Parthia, $541 \mathrm{f}$.

Decline of the Saljüqid Empire, The (M. F. Sanaullah), 258-260.

Dessoulavy (C. D.), rev., 263-9, 545-7.

Devas and Devis, in Khotan, 912-17.

Distinction de l'Essence et de l'Existence d'après Ibn Siña, La (A.-M. Goichon), 248 f.

Divyāvadäna, Note on the (E. J. Thomas), 654-6.

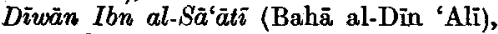
$521 \mathrm{f}$.

Diwani ya Muyaka bin Hājial-Ghassaniy, $1056 \mathrm{f}$.

Doctrine Morale et Métaphysique de Rāmānuja, La (0. Lacombe), 1031, 1044.

DoDwelu (H. H.), rev., $479 \mathrm{f}$.

Doke (Clement M.), Text Book of Lamba Grammar, $811 \mathrm{f}$.

Doughty's English (W. Taylor), $802 \mathrm{f}$.

Dravidian Studies II (T. Burrow), 289 297.

Duchesne-GuThlemin (J.), Indo-Iranica, 925-931.

DUNNE (J. HEYwoRTH), An Introduction to the History of Education in Modern Egypt, 517 f. ; Rifā'ah Badawi Räfi“ aț-Tahțawi, 399-415 ; rev., 518-539.

\section{E}

Early Ivories from Samaria (J. W. and G. M. Crowfoot), 792-4.

East and West (R. Guénon), 1031, $1047 \mathrm{f}$.

East India Company, The Secret Committee of the (C. H. Philips), 299-315, 699-716.

Eastern Religions and Western Thought (Sir S. Radhakrishnan), 1031, 1036-9.

Ebert-Elber (RatPh), Two Mende Tales, 223-234.

Economic Development of Modern Egypt, The (A. E. Crouchley), 535-7.

Economic Problems of Modern India (edit. Radhakamal Mukerjee), $482 \mathrm{f}$.

Edwaros (C. C.), Calligraphers and Artists, 199-211.

Edwards (E. D.), edit., A Chinese Vocabulary of Cham Words and Phrases, 53-91.

Egypt, Bulletin of the Faculty of Arts of the University of, $526 \mathrm{f}$.

Egypt, economic development of Modern, 535-7; education in, 517 f.; feudalism in, 532-4; the minaret in, $527 \mathrm{f}$.
Etssfeutur (OTTo), Ras Schamra und Sanchunjaton, $253 \mathrm{f}$.

Elkin (A. P.), The Australian Aborigines, $489-491$.

English Loan-words in Gujarati, Some (A. Master), 25-30.

Eras and Calendars used in the Countries of Islam, Various (S. H. Taqizadeh), 107-132 ; of Armenia, 648-653.

Esquisse d'une Grammaire Comparée de l'Arménien Classique (A. Meillet), 510.

Essai sur la Langue Parthe (A. Ghilain), $508 \mathrm{f}$.

Éthiopien Méridional, Nouvelles Études d' (M. Cohen), $807 \mathrm{f}$.

Everyday Arabic (H. M. Nahmad and C. Rabin), 801.

\section{$\mathrm{F}$}

Famous Cities of Iran (L. Lockhart). 525.

Färs, A civil and military review in, 141-178.

Feudalism in Egypt, Syria, Palestine, and the Lebanon (A. N. Poliak), 532-4.

Finance in Iran, 755-789.

Fitzgerald (C. P.), rev., 245-7.

FitzGerald (S. Vesey), rev., $822 \mathrm{f}$., 1014.

Foreign Influences on Muslim Theology (A. S. Tritton), 837-842.

Foreign Vocabulary of the Qur'än, The (A. Jeffery), 1009-1111.

FonTes (M.), rev., $549 \mathrm{f}$.

Four Strange Tongues from South Arabia (B. Thomas), $251 \mathrm{f}$.

Fiunftausend Sprichwörter aus Palästina (M. Thilo), $524 \mathrm{f}$.

FuRNIVALL (J. S.), Netherlands India, $244 \mathrm{f}$.

Fyzee (Asaf A. A.), edit., 255-7.

G

Gangolee (N.), Bibliography of Nutrition in India, 815.

Gaselee (Sir Stephen), rev., 497-500.

Gaurana, Navanädhacharitra, 487.

Ghabn fähish, 877-884.

GhIlaIn (A.), Essai sur la Langue Parthe, 508 f.

Giвв (H. A. R.), rev., 797.

Grles (LIONEL), Dated Chinese Manuscripts in the Stein Collection V, 317344.

GoIchoN (A.-M.), La Distinction de l'Essence et de l'Existence d'après Ibn $\operatorname{Sin} \bar{a}, 248 \mathrm{f}$.

Grammar of the Language of Lobaha, A ( $\dagger W$. G. Ivens), $345-363$; of the Lan. guage of Lotora, Maewo, $\mathbf{A}(+W . G$. Ivens), 679-698.

Grant (E.), edit., 2.58.

GREEN (M. M.), Land Tenure in an Ibo Village, $1061 \mathrm{f}$. 
Guillaume (Alfrred), Prophecy and Divination, $247 \mathrm{f}$.

Gujarati, English loan-words in, 25-30. Guthrie (Malcolis), Tone-Ranges in a Two-Tone Language, 469-478.

Gyan Chand, India's Teeming Millions, $821 \mathrm{f}$.

\section{$\mathrm{H}$}

Hackin (J. G.), obituary of, $1067 \mathrm{f}$.

HaIley, Lord, An African Survey, 551-3. Il-Hajja tar-Re u r-Regina Taghna (M. Kissaun), 267.

Hatăy UdHa, Abhidhānaratnamālā, $1049 \mathrm{f}$. Ham, etymology of, 972-5.

Harari, Contributions ̀̀ l'Étude du (W. Leslau), 2.52.

Hartog (Sir Philip J.), Some Aspects of Indian Education Past and Present, $235 \mathrm{f}$.

Hassid (Sanuel), The Sultan's Turrets, $527 \mathrm{f}$.

Hausa, An Introduction to Spoken (R. C. Abrahams), 1057-1061; A Modern Grammar of Spoken Hausa (R. C. Abrahams), 1057-1061.

Haverford Symposium on Archaology and the Bible, The, 258.

Hebrew Chronology (A. Rutherford), $1008 \mathrm{f}$.

Hemann (Betty), rev., 1031-1049.

Henning (W. B.), Mani's Last Journey, 941-953; Sogdian Loan-words in New Persian, 93-106 ; "Sulphur" in Sogdian, 398; rev., 500-510.

Henninger (Josef), Pariastämme in Arabien, 799.

HerzFELD (ERNST), Archaeologische Mitteilungen aus Iran, 501-7.

Heyworth-Dumne (J.). See Dunne.

al-Hidāyatu ' $l-\AA$ Imiriya (al-Āmir biAhkãmi 'llāh), 255-7.

History of Indian Philosophy, $A$ (S. Dasgupta), 1031, 1039-1041; of Kanauj to the Moslem Conquest (R. S. Tripathi), 814; of Shāh Isma $\bar{a}^{\wedge} \bar{\imath}$ Safawi (Ghulīm Sarwar), 1025-8; of the Arabs (P. K. Hitti), $530 \mathrm{f}$.; of Tirupati, $A$ (S. Krishnasvami Aiyangar), $1051-4$.

Hттті (Pнmip K.), History of the Arabs, $530 \mathrm{f}$.

Hovgson (G. H.), Thomas Parry, Free Merchant, 482.

Hoernl. (R. F. Alfred), South African Native Policy and the Liberal Spirit, $810 \mathrm{f}$.

Houtom (D. C.), The National Faith of Japan, 239-242.

HorNer (I. B.), trans. The Book of the Discipline, $1028 \mathrm{f}$.

Hratanica IV (W. H. Bailey), 886-924.

\section{I}

Ibn al."Arabì (Muhyi ul-Dīn), his philosophy, $512 \mathrm{f}$.

IBN AL-MU'TAZz, Tabaqāt al-Shu'arâ al-Muhdathīn, 518-520.

Ibn al-Sā'ātì. See Bahā al-Dīn 'Alì.

Ibn Sīna, philosophy of, $248 \mathrm{f}$.

Ibo Village, Land T'enure in an (M. M Green), $1061 \mathrm{f}$.

Ighäthat al-ummat, $798 \mathrm{f}$.

IkBal Ali Shah, The Spirit of the East, 524.

Al-Ilklīl VIIT, 1009-1012.

Illumination in Islamic Mysticism (Abū Mawāhib al-Shādhilī), 523.

India, Economic Problems of Modern (edit. Radhakamal Mukerjee), $482 \mathrm{f}$.; economics and politics of, 814-823; education in, $235 \mathrm{f}$; The Industrial Worker in (B. Shiva Rao), 483-5; Some Influences that made the British Administrative System in (M. Ruthnaswamy), $479 \mathrm{f}$.

India Office, Catalogue of the Arabic Manuscripts in the Library of the (R. Levy), 796.

Indian Politics since the Mutiny (Sir C. Y. Chintamani), $815 \mathrm{f}$.

Indian Press, The (M. Barns), 819-821.

India's Teeming Millions (Gyan Chand), $821 \mathrm{f}$.

Indo-Iranica (J. Duchesne-Guillemin), 925-931.

Industrial Worker in India, The (B. Shiva Rao), 483-5.

Influence of Chingiz-Khān's Yāsa upon the General Organization of the Mamlük State, The (A. N. Poliak), $862-876$.

al-Inkishafi, $547 \mathrm{f}$.

Introduction to Spoken Hausa, An (R. C. Abraham), 1057-1061; to the History of Education in Modern Egypt, $A n$ (J. Heyworth-Dunne), $517 \mathrm{f}$.

Iran, Archaeologische Mitteilungen aus (E. Herzfeld), 501-7 ; calligraphers and artists of, 199-211; Famous Cities of (L. Lockhart), 525 ; finance in, $755-789$; folklore of, 542-5.

Iranian Festivals Adopted by the Christians, ete., The (S. H. Taqizadeh), $632-653$.

Iranische Dialektaufzeichnungen (F. C. Andreas), $1019 \mathrm{f}$.

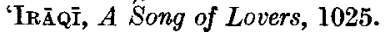

Islam, in Nineteenth-Century South Africa, 213-221; The average man in early, 133-140; The Law of War and Peace in (M. Khadduri), 1014 ; Studies in Popular (S. M. Zwemer), 528 ; in the World (Zakī 'Alī), $528 \mathrm{f}$.

Islamic countries, eras and calendars used in, 107-132.

Islamic textiles, 526 . 
Ismā'il I, Șafawi, Shāh, history of, 1025-8; poetry of, $1006 a-53 a$.

Ismāîlism, 255-7; The Origins of (B. Lewis), 797.

†Ivens (W. G.), A Grammar of the Language of Lobaha, 345-363; A Grammar of the Language of Lotora, Maewo, 679-698 ; rev.. 489-492, 824-6.

\section{$\mathbf{J}$}

Jagmanderlal Jaini, Outlines of Jainism, 1051, 1054.

Jainism, Outlines of (Jagmanderlal Jaini), 1051, 1054.

Japanese, The Alternance $\imath-\sim u$ in Ancient (S. Yoshitake), 666-678.

JEFTERY (A.), The Foreign Vocabulary of the Qur'an, 1009-1011.

Jेeh, 377, 380, 390 f., 609, 612, 620-4

Jewish Source on Damascus just after the Ottoman Conquest, $A$ (B. Lewis), 179-184.

Jews, condemn Iranian festivals, 637-9.

L'Jien' u Lilhinn Minnhu (Dun Karm), $264 \mathrm{f}$.

Johnston (E. H.), rev., 237-9.

\section{$\mathbf{K}$}

Kanauj, History of (R. S. Tripathi), 814. KARM (DUN), L-'Jien' u Lilhinn Minnhu, $264 \mathrm{f}$.

Karmasiddhiprakarạa (Vasubandhu), 237-9.

Karnătaka History, Sources of (S. Srikantha Sāstri), $1051 \mathrm{f}$.

Karst (J.), Précis de Numismatique Géorgienne, 791.

Kashf al-Ghummah, 523.

Kathävatthuppakarana-atthakathā, $1028 \mathrm{f}$.

KEŚIRĀJA, Sabdamanidarpana, 1049 f.

KHaDdURI (MaJio), The Law of War and Peace in Islam, 1014.

Khalaj, The Turkish Dialect of the (V. Minorsky), 417-437.

Khatā'i (i.e. Shāh Ismāìl I), poetry of, $1006 a-53 a$.

KHIN Z

Khoräkābād, dialect of, $420 \mathrm{ff}$.

Khotan, religion of, $886-924$.

Kimpunar, in Jogic, 976-991.

Kin Maung Lat, Burmese Proverbs, 31-51.

Kissaun (MIChaEL), Il-Hajja tar Re $u$ r-Regina Taghna, 267 ; transl., $266 \mathrm{f}$.

Kitāb al-sulük (Maqrīzī), 513.

Kondūrūd, dialect of, $418 \mathrm{ff}$.

Konow (STEN), edit., A Medical Text in Khotanese, 1019, 1021-3.

Krishna (K. B.), The Problem of Minorities, 821.
Krishnasvami Aiyangar (S.), A History of Tirupati, 105]-4.

Krsna-karnämrta (Līlāsuka), 488.

KRUMM (B.), Words of Oriental Origin in Swahili, 808-810.

Kunst (ARNOLD), An Overlooked Type of Inference, 976-991.

Kyin, etymology of, 964-7.

\section{$\mathrm{L}$}

Lacombe (Olivier), La Doctrine Morale et Métaphysique de Rãmānuja, 1031, 1044.

Laesio enormis in Muhammadan Law (W. Mansbach), 877-884.

Lamba Grammar, Text Book of (C. M. Doke), $811 \mathrm{f}$.

Lamotte (É.), Le Traité de l'Acte... Karmasiddhiprakurana, 237-9.

Land T'enure in an Ibo Village (M. M. Green), $1061 \mathrm{f}$.

LANGTon (N. and B.), The Cat in Ancient Eqypt, 806 f.

Law (Bimala Churn), transl. The Debates Commentary, $1028 \mathrm{f}$.

Law of War and Peace in Islam, The (M. Khadduri), 1014.

Lebanon, feudalism in, 532-4.

Lehen il-Malti, 267, 545-7.

LE May (R.), A Concise History of Buddhist Art in Siam, $242 \mathrm{f}$.

Leslad (Wolf), Contributions à l'Étude du Harari, 252.

Lessico T'urco-Italiano (L. Bonelli), 538.

LEVI DELLA VIDA (G.), transl., 250.

Levy (REUBEN), Catalogue of the Arabic Manuscripts in the Library of the India Office, II, iv, 796.

Lewis (BErnard), A Jewish Source on Damascus just after the Ottoman Conquest, 179-184; The Origins of Ismä́i lism, 797 ; rev., 255-7, 485-7, 802-5, 1016-18, 1025 .

LiebERMANn (SaUL), Shkiin, $803 \mathrm{f}$.

Lї̈̈̄́UKA, Krsna-karnāmrta, 488.

Lingala, Tone-ranges in, 469-478.

Literacy in India (R. V. Parulekar), $816 \mathrm{f}$.

Lobaha, A Grammar of the Language of (†W. G. Ivens), 345-363.

LockHart (LAURENCE), Famous Cities of Iran, 525 .

Lovedale: South Africa (R. H. W. Shepherd), $1055 \mathrm{f}$.

LuEe (Sir HaRRY Charles), transl., $266 \mathrm{f}$.

Luzon, Some Undescribed Languages of (M. Vanoverberg), $491 \mathrm{f}$.

\section{M}

Madrasa Nizamiyya et son Histoire, La (Asad Talas), 798. 
Maewo, grammar of the language of Lotora, 679-698.

Magnes Anniversary Book, 804-6.

Mahadevan (T. M. P.), The Philosophy of Advaita, 1031, $1033 \mathrm{f}$.

Malay, Simple, $243 \mathrm{f}$.

Maltese language and literature, 263-9, 545-7.

Il-Malti, $265 \mathrm{f}$.

Mambwe Proverbs (A. Werner), 455-467.

Mamlūk State, Anti-Christian Propaganda in the, 843-861 ; Influence of ChingizKhān's Yāsa upon Organization of the, 862-876.

Mani's Last Journey (W. B. Henning), 941-953.

Mansbach (W.), Laesio Enormis in Muhammadan Law, 877-884.

Manuale di Lingua Turca (E. Rossi), $538 \mathrm{f}$.

AL-MAQRīzī, Kitāb al-sulūk, 513.

Margary Affair and the Chefoo Agreement, The (S. T. Wang), 823.

Margoliouth (D. S.), rev., $517 \mathrm{f}$.

Masst (H.), Croyances et Coutumes Persanes, 542-5.

Master (Alfred), Some English Loanwords in Gujarati, 25-30 ; The Nanda Couplet, 657-665.

Matrhews (Gorjon), The Vulgar Pronunciation of Tamil, 992-7; rev., $812 \mathrm{f}$.

MAYER (L. A.), Bibliography of Muslim Numismatics, $1014 \mathrm{f}$.

Medical Text in Khotanese, $A$ (ed. S. Konow), 1019, 1021-3.

Medieval Trade Routes (J. N. C. Baker), $531 \mathrm{f}$.

Mediterranean in Politics, The (E. Monroe), $534 \mathrm{f}$.

MeEK (C. K.), rev., $1061 \mathrm{f}$.

MeILLT (A.), Esquisse d'une Grammaire Comparée de l'Arménien Classique, 510.

Mende Tales, Two (R. Ebert-Elber), 223-234.

Middle Indian Miscellanies (L. Alsdorf), 19-23.

Mrues (G.), The Numismatic History of Rayy, $1023 \mathrm{f}$.

Minaret and Pipeline (M. Boveri), $485 \mathrm{f}$. ; in Egypt, $527 \mathrm{f}$.

Mrnorsky (V.), A Civil and Military Review in Fārs in $881 / 1476,141-$ 178 ; The Poetry of Shāh Ismā'il I, 1006a-1053a; The Turkish Dialect of the Khalaj, 417-437 ; rev., 258-263, 539-545, 1014 f., 1023-8.

Minorsky (V.) and Minovi (M.), Nașīr al-Dīn Tūsi on Finance, 755-789.

Mit B.-île gebildeten Perfektstämme in den Bantusprachen, Die (P. Berger), $270 \mathrm{f}$.

Modern Grammar of Spoken Hausa, A (R. C. Abraham), 1057-1061.
Monneret de Villard (Uao), Aksum, 254.

Monroe (Eliza BeTH), The Mediterranean in Politics, $534 \mathrm{f}$.

MoOKERJEe (GIrIJA) and ANDrews (C. F.), The Rise and Growth of the Congress, $815 \mathrm{f}$.

Mоотнам (0. H.), Burmese Buddhist Law, $822 \mathrm{f}$.

MorEaU (R. E.), Bird-nomenclature in an East African Area, 998-1006.

Mu'äwiya I, 250.

Muhammad Asad (L. Weiss), transl, of Sahih, $249 \mathrm{f}$.

Muhammad's Bond with the Women (G. H. Stern), 185-197.

MUKERJEe (RadhakaMal), Economic Problems of Modern India (edit.), $482 \mathrm{f}$.

Munro System of British Statesmanship in India, The (K. N. Venkatasubba Sastri), $817 \mathrm{f}$.

Murray (Margaret A.), rev., $806 \mathrm{f}$.

Music, Burmese (Khin Zaw), 717-754.

Muslim Numismatics, Bibliography of, $1014 \mathrm{f}$.

Muslim Theology, Foreign Influences on (A. S. Tritton), 837-842.

MUYAKa, Diwani ya Muyaka, $1056 \mathrm{f}$.

Mystical Philosophy of Muhyid DinIbnul 'Arabi, The (A. E. Affifi), $512 \mathrm{f}$.

\section{$\mathrm{N}$}

Nāgas, in Khotan, $915 \mathrm{f}$.

NAHMAD (H. M.) and RABIN (C.), Everyday A rabic, 801.

Naivãsikas, in Khotan, 917-19.

Nallino (C. A.), Raccolta di Scritti Editi e Inediti, 1016 f.

Nanda Couplet, The (A. Master), 657665 .

Nașir al-Dīn Tūsī on Finance (M. Minovi and $\dot{\mathrm{V}}$. Minorsky), 755-789.

National Faith of Japan, The (D. C. Holtom), 239-242.

Navanādhacharitra (Gaurana), 487.

Netherlands India (J. S. Furnivall), $244 \mathrm{f}$.

New Indian Antiquary, $236 \mathrm{f}$.

Nominale Klassifikatie in de Afrikaansche Negertalen, De (J. Wils), 269 f.

Note on ... Sir George Grierson's MSS. etc. (H. N. Randle), 1066; on the Divyāvadāna (E. J. Thomas), 654-6.

Notes on Anti-Christian Propaganda in the Mamlūk Empire (M. Perlmann), 843-861.

Nouvelles Études d'Ethiopien Méridional (M. Cohen), $807 \mathrm{f}$.

Nubian, A Study in Medieval (B. H. Stricker), 439-454.

Numismatic History of Rayy, The (G. Miles), $1023 \mathrm{f}$. 
0

Obituary notices :-

J. G. Hackin, $1067 \mathrm{f}$.

Sir E. D. Ross, 832-6.

O'LeARY (DE LACY), Arabic Thought and its Place in History, 513.

Oriental Mysticism (E. H. Palmer), 526.

Origins of İsma' $i$ ilism, The (B. Lewis), 797.

Outlines of Jainism (Jagmanderlal Jaini), 1051, 1054.

Overlooked Type of Inference, An (A. Kunst), 976-991.

\section{$\mathbf{P}$}

Palæography, Specimens of Arabic and Persian (A. J. Arberry), 802.

Palestine, feudalism in, 532-4; proverbs of, $524 \mathrm{f}$.; Quarterly of the Department of Antiquities in, X, 1, $1007 \mathrm{f}$.

Palmer (E. H.), Oriental Mysticism, 526.

Panjab, Another Ancient Tribe of the (L. D. Barnett), 277-284.

Pariastämme in Arabien (J. Henninger), 799.

Parry (Thomas), 482.

Parthia, history of, $541 \mathrm{f}$.

Parthian language, $508 \mathrm{f}$.

Partugkar (R. V.), Literacy in India, $816 \mathrm{f}$.

Perfektstämme in den Bantusprachen, Die mit B.-île gebildeten (P. Berger), $270 \mathrm{f}$.

Perlmann (M.), Notes on Anti-Christian Propaganda in the Mamlūk Empire, 843-861.

Persia, folklore of, 542-5.

Persian, Sogdian loan-words in New, 93-106; Simple Colloquial (C. L. Hawker), 261-3.

Persian Literature (C. A. Storey), 539-541.

Phénicie et l'Asie occidentale, La (R. Weill), 1007.

Phildy (H. St. J. B.), Sheba's Daughters, $514 \mathrm{f}$.

Phulps (C. H.), The Secret Committee of the East India Company, 299-315, 699-716 ; rev., 480-5, 814-823.

PhInlIPS (RAY E.), The Bantu in the City, $549 \mathrm{f}$.

Philosophy of Advaita, The (T. M. P. Mahadevan), 1031, $1033 \mathrm{f}$.

Pinto (OlaA), transl., 250.

Poetry of Shāh Ismā'ill I, The (V. Minorsky), 1006a-1053a.

Poliak (A. N.), Feudalism in Egypt, Syria, Palestine, and the Lebanon, 532-4; The Influence of ChingizKhān's Yāsa upon the General Organization of the Mamlūk State, 862-876.

Political History of Parthia, A (N. C. Debevoise), 541 f.
Positive Background of Hindu Sociology, The (B. K. Sarkar), 1031, $1034 \mathrm{f}$.

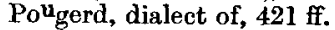

Précis de Numismatique Géargienne (J. Karst), 791.

Problem of Minorities, The (K. B. Krishna), 821.

Prophecy and Divination (A. Guillaume), $247 \mathrm{f}$.

\section{$Q$}

Qafar-Khafara (E. Combe), 790.

Qal wa-homer type of inference, 986991.

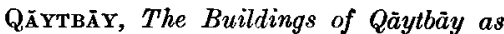
described in his Endowment Deed, $529 \mathrm{f}$.

Quarterly of the Department of Antiquities in Palestine, $\mathrm{X}, 1,1007 \mathrm{f}$.

Qur'an, The (transl. R. Bell), 511; The foreign vocabulary of the, 10091111.

\section{B}

Rabin (C.) and Nahmad (H. M.), Every. day Arabic, 801.

Raccolta di Scritti Editi e Inediti (C. A. Nallino), $1016 \mathrm{f}$.

RaDHAKRISHNAN (Sir S.), Eastern Religions and Western Though, 1031, 1036-9.

Rakkont ta' Safra fl-Art Imqaddsa, $266 \mathrm{f}$.

Rãma (H. W. Bailey), 365-376, 559598.

Ramachandra Dikshytar (V.R.), transl. of Silappadikāram, $812 \mathrm{f}$.

Ratple (H. N.), Note on ... Sir George Grierson's MSS., ete., 1066.

Ras Schamra und Sanchunjaton (O. Eissfeldt), $253 \mathrm{f}$.

Ras Shamra, The Cuneiform Texts of (C. F. A. Schaeffer), $252 \mathrm{f}$.

Rayy, numismatic history of, $1023 \mathrm{f}$.

Recherches sur l'étymologie des deux dialectes tokhariens (A. J. van Windekens), 932-940.

Redressement Économique et Industrialisation de la Nouvelle Turquie (O. Conker and É. Witmeur), 1016-18.

RGGAMEY (K.), Three Chapters from the Samädhirājasūtra, 1030.

Reitulnatr (GERALD), South of the Clouds, 245-7.

Rejoinder, A (A. J. Arberry), $1065 \mathrm{f}$.

Religion Musulmane en Berbérie, La (A. Bel), 515-17.

RENoU (LovIs), Sur certains emplois $d^{\prime} a(n)^{\circ}$ priv. en sanskrit, 1-18.

RICHaRds (F. J.), rev., $242 f$.

Rifā'ah Badawì Räfi' at-Tahțawī (J. Heyworth-Dunne), 399-41.5.

Rise and Growth of the Congress, The (C. F. Andrews and G. Mookerjee), $815 \mathrm{f}$. 
Rise of the North Arabic Script and its Kur'anic Development, The (N. Abbott), 794-6.

Rochlin (S. A.), Aspects of Islam in Nineteenth-Century South Africa, 213221.

Ross (Sir E. D.), obituary of, 832-6a.

Rossi (EtToRe), L'Atabo Parlato a $S_{S} a n^{6} \hat{a}^{\prime}, 801 \mathrm{f.} ; \quad$ Manuale di Lingua Turca, $538 \mathrm{f}$.

Rotuman Legends (transl. by C. M. Churchward), 824-6.

RUTHERFORD (A.), Hebrew Chronology, $1008 \mathrm{f}$.

Ruthnaswamy (M.), Some Influences that made the British Administrative System in India, $479 \mathrm{f}$.

\section{S}

Sabdamanidarpaña (Keśirāja), 1049 f.

Sahīh al-Bukhärì, transl. by Muhammad Asad, $249 \mathrm{f}$.

Samädhiräjasūtra, Three Chapters from the (K. Régamey), 1030.

Samaria, ivories from, 792-4.

$S_{S a n} \hat{a}^{\prime}, L^{\prime} A r a b o$ parlato a (E. Rossi), $80 \mathrm{I}$.

Sanatulah (M. F.), The Decline of the Saljüqid Empire, 258-260.

Sanchunjuton, Ras Schamra und (O. Eissfeldt), $253 \mathrm{f}$.

ŚANTINātha, Sädhu, The Critical Examination of the Philosophy of Religion, 1031 f. ; Māyāvāda, 1031-3.

Sarkar (Benoy Kumar), The Positive Background of Hindu Sociology, 1031, $1034 \mathrm{f}$.

Sarwar (Gholam), History of Shāh Ismā’il Safawì 1025-8.

Sáta and $\dot{S a} t i$ in place-names, $284 \mathrm{f}$.

SchatfFER (C. F. A.), The Cuneiform Texts of Ras Shamra, $252 \mathrm{f}$.

Science chez les Turcs Ottomans, La (A. Adnan), $486 \mathrm{f}$.

Secret Committee of the East India Company, The (C. H. Philips), 299 315, 699-716.

Selections of Zātspram, 377-398.

Seljuks, 258-260.

Sheba's Daughters (H. St. J. B. Philby), $514 \mathrm{f}$.

ShEPHERd (R. H. W.), Lovedale: South Africa, $1055 \mathrm{f}$.

Shinto, 239-242.

SHIva RAO (B.), The Industrial Worker in India, 483-5.

Shkiin (S. Liebermann), $803 \mathrm{f}$.

Shuja-ud-Daulah (Ashirbadi Lal Srivastava), $818 \mathrm{f}$.

Siam, Buddhist art in, $242 \mathrm{f}$.

Silappadikāram, The (transl. by V. R. Ramachandra Dikshitar), $812 \mathrm{f}$.
Șilat al-șila (Abū Ja'far Ahmmad b. al-Zubair), 522.

StmoN (W.), Tibetan dân, ciñ, kyin, yin, and ham, 954-975.

Simple Colloquial Persian (C. L. Hawker), 261-3.

Simple Malay (Sir R. O. Winstedt), $243 \mathrm{f}$.

Sinhalica (L. D. Barnett), $287 \mathrm{f}$.

Syith (Sidney), Alalakh and Chronology, 791 f. ; rev., 492-7.

Sogdian Loan-words in New Persian (W. B. Henning), 93-106.

Some Aspects of Indian Education Past and Present (Sir P. J. Hartog), $235 \mathrm{f}$.

Some Influences that made the British Administrative System in India (M. Ruthnaswamy), $479 \mathrm{f}$.

Some Undescribed Languages of Luzon (M. Vanoverberg), $491 \mathrm{f}$.

Song of Lovers, $A$ ('Irāqī), 1025.

Sons of Sindbad (A. Villiers), 1009, $1013 \mathrm{f}$.

Sources of Karnātaka History (S. Srìkaṇța Sāstri), $105 \mathrm{l}$ f.

South African Native Policy and the Liberal Spirit (R. F. A. Hoernlé), 810 f.

South of the Clouds (G. Reitlinger), 245-7.

Specimens of Arabic and Persian Palæography (A. J. Arberry), 802.

SpIEss (O.), Verzeichnis der Schriften von C. Brockelmann, 802.

Spirit of the East, The (Ikbal Ali Shah), 524.

ŚRİkAṆTha Śāstri (S.), Sources of Karnütaka History, $1051 \mathrm{f}$.

Srivastava (Ashirbadi LaL), Shuja-udDaulah, $818 \mathrm{f}$.

Standard English-Swahili Dictionary, A, $548 \mathrm{f}$.

Standard Swahili-English Dictionary, A, $548 \mathrm{f}$.

StARK (Freya), A Winter in Arabia, $799 \mathrm{f}$.

StEde (W.), rev., $1028 \mathrm{f}$.

Stein Collection, Dated Chinese MSS. in the, $V$ (L. Giles), 317-344.

Stern (Gertrude H.), Muhammad's Bond with the Women, 185-197.

Storey (C. A.), Persian Literature, $539-541$.

Stricker (B. H.), A Study in Medieval Nubian, 439-454.

Studies in Popular Islam (S. M. Zwemer), 528.

Study in Medieval Nubian, A (B. H. Stricker), 439-454; of some early Islamic Textiles in the Museum of Fine Arts, Boston, A (N. P. Britton), 526.

"Sulphur" in Sogdian (W. B. Henning), 398.

Sultan's Turrets, The (S. Hassid), $527 \mathrm{f}$.

Setton (L. P. Elwell), rev., $801 \mathrm{f}$. 
Swahili, Words of Oriental Origin in (B. Krumm), 808-810; language, $548 \mathrm{f}$.

Syria, feudalism in, 532-4.

\section{$\mathbf{T}$}

Tabaqāt al-Shu'arā al-Muhdathīn (Ibn al-Mu'tazz), 518-520.

TABor (D.), rev., $805 \mathrm{f}$.

Taghlim fuq il-Kitba Maltija (A. Cremona), $268 \mathrm{f}$.

Taht Tliet Saltniet (G. Aquilina), $263 \mathrm{f}$.

Talas (AsaD), La Madrasa Nizamiyya et son Histoire, 798.

Tales of a Lonely Island: Rotuman Legends (transl. by C. M. Churchward), 824-6.

Tamil, vulgar pronunciation of, 992-7; literature, $812 \mathrm{f}$.

TaqIZadeh (S. H.), Various Eras and Calendars used in the Countries of Islam, 107-132 ; The Iranian Festivals Adopted by the Christians, etc., 632653.

Tatimmat Șiwān al-Hikmah (al-Baihaqī), $520 \mathrm{f}$.

Tattvabindu (Vāchaspati Miśra), 1031, 1045-7.

TaYLOR (WALT), Doughty's English, $802 \mathrm{f}$.

Tell el-Amarna Tablets, The (edit. S. A. B. Mercer), 492-7.

Text Book of Lamba Grammar (C. M. Doke), $811 \mathrm{f}$.

ThIL (MarTIN), Fünftausend Sprichwörter aus Palästina, $524 \mathrm{f}$.

Thomas (Bertram), frour Strange Tongues from South Arabia, $251 \mathrm{f}$.

Thomas (E. J.), Note on the Divyāvadāna, 654-6.

Thomas Parry, Free Merchant (G. H. Hodgson), 482.

Three Chapters from the Samādhirājasūtra (K. Régamey), 1030.

Tibetan dan, cin̂, kyin, yin, and ham (W. Simon), 954-975.

Tirupati, $A$ History of (S. Krishnasvami Aiyangar), 1051-4.

Tokharian dialects, etymologies of, 932-940.

Tone-Ranges in a Two-Tone Language (M. Guthrie), 469-478.

Tongas (GGrard), Ataturk and the True Nature of Modern Turkey, 537.

Trade Routes, Medieval (J. N. C. Baker), $531 \mathrm{f}$.

Traité de l'Acte, Le (Vasubandhu), 237-9.

Transfiguration, feast of, 637, 640-9, 653.

Tripathi (Rama ShankaR), History of Kanauj, 814.

Tritron (A. S.), The Average Man in Early Islam, 133-140; Foreign Influences on Muslim Theology, 837-
842 ; rev., 247-254, 511-15, 794-6 798-801, 807-810, 1009-1014.

Ttägutta (H. W. Bailey), 599-605.

TUCKER (A. N.), rev., 269-271, 551-3, $811 \mathrm{f}$.

Turkey, economic reconstruction of, 1016-18.

Turkish Dialect of the Khalaj, The (V. Minorsky), 417-437; language, $538 \mathrm{f}$.

Turks, Science anıong Ottoman, $486 \mathrm{f}$.

TuRner (R. I.), Ohituary : Sir Edward Denison Ross, 832-6.

\section{V}

V̄̄ChaspatTI MIŚRA, Tattvabindu, I031, 1045-7.

Vaidyanatha Aysar (R. S.), After the Reforms: Communal versus Democratic Psychology, 814.

VANoverberg (Morice), Some Undescribed Languages of Luzon, $491 \mathrm{f}$.

Vardavar (Transfiguration), 637, 640-9, 653.

Varia Coptica (W. E. Crum), $497 \mathrm{f}$.

Vasubandhu, Le Traité de l'Acte de Vasubandhu, Karmasiddhiprakarana, 237-9.

Venkatasubba Sastri, K. N., The Munro System of British Statesmanship in India, $817 \mathrm{f}$.

Verzeichnis der Schriften von Carl Brockelmann (O. Spiess), 802.

Viltiers (AraN), Sons of Sindbad, 1009, $1013 \mathrm{f}$.

Vinaya-pitaka, $1028 \mathrm{f}$.

Vulgar Pronunciation of Tamil, The (G. Matthews), 992-7.

Wang (S. T.), The Margary Affair and the Chefoo Agreement, 823.

\section{W}

WaRd (IDA C.), rev., $1055 \mathrm{f}$.

WARD (L. S.), rev., 1057-1061.

Warren Hastings and Oudh (C. Collin Davies), $480 \mathrm{f}$.

Wayfarer's Words (C. A. F. Rhys Davids), 1031, $1044 \mathrm{f}$.

WAYRIFFE (U.), Arubica and Islamica, $1009,1012 \mathrm{f}$.

WEnL (R.), La Phénicie et l'Asie occiden. tale, 1007.

Wetr (Cecil J. Mullo), rev., $791 \mathrm{f}$.

†Werner (Alice), Mambwe Proverbs, 455-467.

WILs (J.), De Nominale Klassifikatie in de Afrikaansche Negertalen, $269 \mathrm{f}$.

WINDEK ENS (A. J, vaN), Recherches sur l'étymologie des deux dialectes tokhariens, 932-940.

Winstedt (Sir Richard O.), Simple Malay, 243 f. ; rev., 244 f. 
Winter in Arabia, $A$ (F. Stark), $799 \mathrm{f}$. Witmeur (Émile). See Conker (O.) and Witmeur (É.).

Words of Oriental Origin in Swahili (B. Krumm), 808-810.

\section{$\mathbf{Y}$}

Yin, etymology of, 967-972.

Yoshrtake (S.), The Alternance $\imath-\sim u$. in Ancient Japanese, 666-678; rev. 239-242.

Yünnan, travels in, 245-7.
Z

Zafhner (R. G.), A Zervanite Apocalypse, 377-398, 605-631.

ZAK' 'ALì, Islam in the World, $528 \mathrm{f}$.

ZĀTSPRAM, Selections, 377-398, 605-631. Zervanite Apocalypse, A (R. C. Zaehner), 377-398, 605-631.

Zurvān, 380, 391, 609, 622.

Zwemer (Samuel M.), Studies in Popular Islam, 528. 


\section{REVIEWS OF BOOKS}

Ta Phénicie et l'Asie ocidentole. Par R. Weill (R. D. Barmett)

The Quarterly of the Department of Antiquities in Palestine, Vol. X, No. 1 (R. D. Barnett) . . . . . . . . . . 1007

Hebrew Chronology. By A. Rutherford (S. Birnbaum). . . . . 1008

The Foreign Vocabulary of the Qur'ān. By A. Jeffery (A. S. Tritton) . 1009

Al-Iklil. Edited by N. A. Faris (A. S. Tritton) . . . . . . . 1009

Arabica and Islamica. By U. Wayriffe (A. S. Tritton) . . . . . . 1009

Sons of Sinbad. By A. Villiers (A. S. Tritton) . . . . . . . 1009

The Law of War and Peace in Islam. By Majid Khadduri (S. V. FitzGerald) . 1014

Bibliography of Muslim Numismatics. By L. A. Mayer (V. Minorsky) . 1014

Raccolta di Scritti, Vol. I. By C. A. Nallino (B. Lewis) . 1016

Redressement Économique et Industrialisation de la Nouvelle Turquie. By O. Conker and É. Witmeur (B. Lewis). . . . . 1016

Iranische Dialektaufzeichnungen aus dem Nachlass von F. C. Andreas (H. W. Bailey) . . . . . . . . . . . . 1019

The Avesta Codex K5, second part (H. W. Bailey) ～～～～～～～. 1019

Codices Sogdiani. By E. Benveniste (H. W. Bailey) . . . . . 1019

A Medical Text in Khotanese. Edited by Sten Konow (H. W. Bailey) . $\quad 1019$

The Numismatic History of Rayy. By G. Miles (V. Minorsky) . . . . . 1023

A Song of Lovers. By 'Irāqī (B. Lewis) . . . . . . . . . 1025

History of Shāh Ismā‘̄il Șafawi. By Ghulām Sarwar (V. Minorsky) 1025

The Debates Commentary. Translated by Bimala Churn Law (W. Stede) 1028

The Book of the Discipline, Vol. II. Translated by I. B. Horner (W. Stede) . 1028

Three Chapters from the Samādhirājasūtra. By K. Régamey (H. W. Bailey) . 1030

The Critical Examination of the Philosophy of Religion. By Sadhu Sāntinātha

(B. Heimann) . . . . . . . . . . . 1031

Māyāvāda. By Sãdhu S̄āntinātha (B. Heimann) . . . . . 1031

The Philosophy of Advaita. By T. M. P. Mahadevan (B. Heimann) · 1031

The Positive Background of Hindu Sociology. By Benoy Kumar Sarkar

(B. Heimann) . . . . . . . . . . . 1031

Eastern Religions and Western Thought. By Sir S. Radhakrishnan (B. Heimann) . . . . . . . . . 1031

A History of Indian Philosophy. By Surendranath Dasgupta. Vol. III (B. Heimann) . . . . . . . 1031

The Cultural Heritage of India, Vol. I (B. Heimann) . . . . . 1031

La Doctrine Morale et Metaphysique de Rāmänuja. By O. Lacombe (B.

Heimann) . . . . . . . . . . . 1031

Wayfarer's Words. By Mrs. Rhys Davids (B. Heimann) . . . . . 1031

Tattvabindu with Tattvavibhāvanā. Edited by V. A. Rãmaswāmi Sāstri (B. Heimann) . . . . . . . . . . . 1031

East and West. By R. Guénon (B. Heimann) . . . . . 1031 